\title{
Legal Protection for Micro and Medium Enterprises Based on the Job Creation Act
}

\author{
David Eka Prasetya ${ }^{1}$, Azis Budianto ${ }^{2}$ \\ \{oryzagrass@gmail.com¹, azis_budianto@borobudur.ac.id² \\ Universitas Borobudur, Jakarta, Indonesia ${ }^{1,2}$
}

\begin{abstract}
This paper discusses the legal protection for micro and medium enterprises based on the Job Creation Act. As an analytical tool, normative juridical research methods are used along with literature studies as a data collection tool. The results indicate that the Job Creation Act provides legal protection for micro and medium enterprises. Issues that need to be observed are related to the law and accounts payable to partners. Therefore, it is necessary to socialize and assist legal services when dealing with the law.
\end{abstract}

Keywords: Law; Micro Enterprise; Job Creation Law

\section{Introduction}

Article 34 passage (1) of the 1945 Constitution of the Republic of Indonesia (UUD 1945) peruses: "The state fosters a federal retirement aide framework for all individuals and enables the frail and inadequate after human pride." the article portrays social government assistance. Circling back to the command of the 1945 Constitution, the public authority has controlled the assurance of Micro, Small, and Medium Enterprises. Inside Law Number 20 of 2008, endeavors have been made to specify the capacities and privileges of MSMEs in making a move against financial development. Moreover, the law requires neighborhood legislatures to secure in the space of financing and venture. [1]

The Employment Creation Bill's existence is expected to change the economic structure that can move all sectors to encourage economic growth to reach 5.7 percent to 6 percent through quality jobs. The intentions are to increase investment to enhance income and power purchase, and it can encourage consumption growth, and increase productivity which will be followed by the increase in wages, ability to pay, and consumption. The development still causes controversy amid society even after the Job Creation Law has been ratified. The rejection of the job creation law also came to the fore because it was considered more in favor of large businesses and foreign investment. The law ignored the protection arrangements regarding employment issues, the environment, and natural resources. Some people even think that the government is only pursuing an increase in doing business (ease of doing business). This paper discusses the legal protection for micro and medium enterprises based on the Job Creation Act. 


\section{Method of Study}

The research was conducted systematically by using normative juridical research.[2] Standardizing juridical exploration is a legitimate examination library or optional information. The examination zeroed in on looking at the utilization of rules or standards in sure law, particularly lawful assurance for MSMEs. The collected data was then analyzed by descriptive analysis and presented analytically and comprehensively.[3]

\section{Discussion}

The Omnibus Law concept has been implemented through a process of simplifying regulations related to investment, as seen in Unofficial law Number 24 of 2018 concerning Electronically Integrated Business Licensing Services, also called Online Single Submission (OSS), which intends to speed up business permitting. The degree to which OSS execution has an effect and advantage for the local area requires further review. Omnibus Law is relied upon to be a forward leap. On the other hand, it is commonly used in the Common Law legal system, while Indonesia adheres to the Civil Law legal system, which some experts fear will disrupt the Indonesian constitutional system.

As part of the world community, Indonesia is bound by the agreements contained in the legal instruments of international treaties. In such circumstances, the norms governing various transnational activities must be able to accommodate rights and obligations as well as common interests between countries, through the creation of new legal patterns needed to regulate relations between countries and between peoples of countries, whose volume is getting bigger, the intensity is powerful, and the more complex the material.

As indicated by Burkhardt Krems, as cited by Attamimi, the development of enactment is anything but a simple juridical action,[4] yet, an interdisciplinary action so the subsequent lawful items can be acknowledged and perceived by the homegrown local area and can oblige the interests of the world local area in the country wherein Indonesia is a part. The assembled guidelines should adjust different interests with the goal that every nation regards each other's sway to decide its venture law strategies. In any case, every nation should likewise secure and treat speculation exercises in its country with practically no segregation between unfamiliar financial backers and homegrown financial backers, just as between unfamiliar financial backers and homegrown financial backers, and individual unfamiliar financial backers. This standard underscores the fundamental rule of securing the equilibrium of interests between each party by regarding one another and giving treatment without segregation.

In the investment sector, legal certainty is very supportive of the creation of a healthy business climate. This factor is needed for a long time because the greater the amount of investment invested, the higher the demand for legal certainty by investors, both philosophical, sociological, and juridical aspects. The profound phase of financing is to open up and provide business opportunities with powerful legal certitude. Therefore, the basic philosophy of Law Number 25 of 2007 concerning Investment is expected to be instrumental for investment, and not vice versa, becomes an obstacle to the business world. Of course, the hope then is to add more property to improve the economy.

The sociological viewpoint through venture will be an increment in speculation that can tackle the issue of joblessness and destitution on the grounds that the public authority financial 
plan isn't sufficient to defeat these two things. The situation of individuals' monetary entertainers is epitomized in the guideline with respect to the advancement of speculation for miniature, little, medium enterprises and cooperatives. The juridical perspective identified with Law Number 25 of 2007 concerning Investment is the lawful reason for doing the order of the 1945 Constitution as a protected premise by considering Article 33 where the public authority in speeding up public monetary turn of events and understanding Indonesia's political and financial power requires expanded venture to handling financial potential into genuine monetary strength by utilizing capital beginning from inside the nation and abroad.

Legal protection is an element that must exist in a country. Every state formation must have a law in it to regulate its citizens. In a country, there must be a relationship between the state and its citizens. Law is a rule that compels but does not force something on someone but protects human interests. It is because matters are often threatened or violated by certain parties so that the law needs to protect them, and if necessary, force them.

Philipus M. Hadjon contended that lawful insurance for individuals is separated into two kinds, to be specific preventive lawful assurance and oppressive lawful security. [5] In preventive legitimate security, individuals can present their complaints or feelings before an administration choice gets an authoritative structure. In this manner, abusive lawful security intends to determine questions. Preventive lawful assurance is profoundly huge for government activities dependent on opportunity of acts on the grounds that with preventive legitimate security the public authority is urged to be cautious in settling on choices dependent on prudence. By this agreement, the public authority in dealing with lawful security for individuals and the local area is remembered for the class of preventive and harsh lawful insurance.

Legal protection in Dutch is called rechtsbecherming. Harjono tries to provide an understanding of legal protection as protection by using legitimate means of protection provided by law, aimed at protecting specific interests, namely by making the interests that need to be protected into a legal right. It can say that legal protection is protection that is provided based on laws and regulations. Interpretation of Lawful security is an activity or work to shield the local area from subjective activities by specialists that are not observing the guideline of law, to make request and harmony to permit people to partake in their pride as individuals.[6]

The meaning of MSMEs is directed in the Law of the Republic of Indonesia Number 20 of 2008 concerning MSMEs. Article 1 expresses that miniature endeavors are useful organizations claimed by people and individual business elements that satisfy miniature undertakings as specified in the Act. Independent venture is a useful financial business that remains solitary, which is completed by people or business substances that are not auxiliaries or parts of organizations that are claimed, controlled, or become part of either straightforwardly or by implication from miniature endeavors or enormous organizations that meet the models of private companies as directed in the law. In the interim, medium-sized organizations are useful financial organizations that independent, which are completed by people or business substances that are not auxiliaries or not parts of organizations possessed, controlled, or become part of either straightforwardly or by implication from miniature ventures, limited scope organizations, or huge organizations that meet the measures for miniature endeavors as alluded to in the law.[7]

Indonesia, which is currently at the level of an agricultural nation, is effectively assembling the economy through MSMEs. The public authority caused different sorts of approaches to proceed to empower the development and improvement of MSMEs. With regards to creating MSMEs as an essential solidarity to speed up local turn of events, first, the 
potential for creating MSMEs in the areas is gigantic. Second, the advancement of MSMEs should be completed under the nearby culture and the capability of the area concerned. Third, the MSME area assumes a fundamental part in handling social issues in regions with extremely high work retention. Fourth, the job of expanding HR, usage of innovation, admittance to capital, admittance to showcasing, admittance to data, and the board are essential in creating miniature ventures. Fifth, normal and HR and world business sectors that are progressively open in the worldwide period have incredible potential in case they are overseen successfully as organizations. The most troublesome obstructions looked by little business people are identified with capital, organization monetary administration, admittance to promoting, and the focal point of a multi business. Business openings for MSMEs have as of late become smaller in light of the fact that the exercises that MSMEs can do are taken over by tremendous organizations.

The public authority's arrangement with the MSME area is plain through Law No. 20 of 2008 concerning MSMEs. It is on the grounds that the public authority is extremely keen on securing and fostering the MSME area. Then, at that point, the law was kept with Government Regulation (PP) No. 17 of 2013 concerning the Implementation of Law No. 20 of 2008. A urgent point managed in this PP is the job of the focal government and nearby legislatures to work with the advancement of MSMEs. One of them is focusing on MSMEs to partake in labor and products obtainment programs held by the public authority.[8]

The form of protection is fostering and developing MSMEs and cooperatives through partnership programs, training, increasing competitiveness, innovation and market expansion, access to finance, and the broadest possible dissemination of information. Also, the ease of doing business for MSME actors can be seen through the exception of the minimum wage provisions for micro and small businesses. Article $90 \mathrm{~B}$ of the Employment Creation Law stipulates that the minimum wage for micro and small companies is determined based on an agreement between employers and workers without the need to follow the minimum wage standards from the government.

Then, in the Job Creation Law as well, MSMEs do not have to fulfill the obligation to give awards or bonuses as referred to in Article 92. Regarding licensing, in the Job Creation Law, licensing provisions are regulated in Article 91 is explained that MSME registration can be done online or offline. It is enough to attach an Identity Card (KTP) and a business certificate from the RT (Neighborhood Association) so that MSME business actors can then obtain a Business Identification Number (NIB) through an electronic business license. Meanwhile, the business registration number is a single license that applies to all business activities. Furthermore, regarding Article 92, Micro and Small Businesses are given convenience or simplification of tax administration in the context of applying for financing facilities from the central government following the provisions of laws and regulations in the field of taxation, in paragraph (2) Micro and Small Businesses that apply for business licenses can give incentives in the form of no fees or fee waivers.

\section{Conclusion}

Generally, the problems faced by MSMEs are related to the law, accounts payable, tight business competition, difficulty in raw materials, lack of knowledge of financial management, and an unfavorable business climate. The development of MSMEs is one of the efforts made by the government to increase investment and create jobs. These efforts are contained The public power's course of action with the MSME region is plain through Law No. 20 of 2008 
concerning MSMEs. It is because the public authority is incredibly enthused about getting and cultivating the MSME region. Then, the law was kept with Government Regulation (PP) No. 17 of 2013 concerning the Implementation of Law No. 20 of 2008. A dire point oversaw in this PP is the occupation of the central government and close by lawmaking bodies to work with the progression of MSMEs. One of them is zeroing in on MSMEs to participate in labor and items acquisition programs held by the public power.

\section{References}

[1] A. Abidin, "Pengembangan Usaha Micro Kecil Dan Menengah (UMKM) Sebagai Kekuatan Strategis Dalam Mempercepat Pembangunan Daerah [Development of Micro, Small and Medium Enterprises (MSMEs) as a Strategic Strength in Accelerating Regional Development]," AKMEN J. Ilm., vol. 5, no. 4, 2008.

[2] D. L. Sonata, "METODE PENELITIAN HUKUM NORMATIF DAN EMPIRIS: KARAKTERISTIK KHAS DARI METODE MENELITI HUKUM [NORMATIVE AND EMPIRICAL LEGAL RESEARCH METHODS: SPECIFIC CHARACTERISTICS OF LEGAL RESEARCH METHODS]," FIAT JUSTISIAJurnal Ilmu Huk., 2015, doi: 10.25041/fiatjustisia.v8no1.283.

[3] I. M. P. Diantha, "Normative Legal Research Methodology," Teor. Metodol. Penelit. a., 2017.

[4] I. Soepomo, "Introduction to Labor Law." Djambatan, Jakarta, 2003.

[5] P. M. Hadjo, Legal Protection for the People. Surabaya: Bina Ilmu, 2010.

[6] S. S. Atin Wirantika*, "PELAKSANAAN PERLINDUNGAN HUKUM BAGI PEKERJA/BURUH PESERTA BPJS KESEHATAN DALAM PELAYANAN DI RUMAH SAKIT BHAYANGKARA INDRAMAYU [IMPLEMENTATION OF LEGAL PROTECTION FOR HEALTH BPJS PARTICIPANT WORKERS/LAWERS IN SERVICES AT BHAYANGKARA INDRAMAYU HOSPITAL]," Diponegoro Law Rev., 2016.

[7] Kurniastuti, "Perlindungan Hukum Usaha Mikro Kecil Menengah (Umkm) Dari Dampak Adanya Perjanjian Asean-China Free Trade Area (Acfta) [Legal Protection of Micro, Small and Medium Enterprises (MSMEs) from the Impact of the Asean-China Free Trade Area (Acfta) Agreement]," J. Manaj. dan Kebijak. Publik, vol. 4, no. 2, 2017.

[8] A. P. Sitorus, "PPolitics of Law on the Protection of Micro, Small and Medium Enterprises (MSMEs) in the Asean Economic Community," Doktrina J. Law, vol. 1, no. 2, 2018. 